\title{
Improving public agency performance using balanced scorecard in Lagos Internal Revenue Service (LIRS)
}

\author{
Jacob Olufemi Fatilea, Ogunlela Yemisib ${ }^{b}$ Akindele lyiola Tomilayoc, Oluwole Kazeem Sannid \\ a Faculty of Management Sciences, Lagos State University, Nigeria. Jacofem@gmail.com, jacob.fatile@lasu.edu.ng \\ ${ }^{b}$ Faculty of Management Sciences, National Open University of Nigeria, Nigeria.mycie2004@yahoo.com \\ c Faculty of Management Sciences, University of Ilorin, Kwara State, Nigeria.wuratomi427@gmail.com \\ d Faculty of Management Sciences, Lagos State University, Nigeria.wuratomi427@gmail.com \\ ${ }^{*}$ Corresponding author.
}

Received: 1 July 2019, revised: 21 August 2019, accepted: 7 September 2019, published: 18 September 2019.

\begin{abstract}
Improving public agency performance vis-à-vis productivity is the greatest challenge facing the public sector. The main objective of this study is to determine the effectiveness of performance measurement using balanced scorecard (BSC) in Lagos Internal Revenue Service (LIRS). Primary and secondary data were utilized for the study. The primary data collected was analyzed using both descriptive and inferential statistics. Descriptive statistics, such as frequency tables and simple percentages, were used in data presentation and analysis. while the stated hypotheses were tested using Regression Analysis. The study adopts the theory of change (ToC) postulated by Weiss as a theoretical basis. The findings of the study reveal that using the balanced scorecard to measure performance periodically with stakeholders' reflection in LIRS has increased significantly the annual revenue generation in Lagos State. The study recommends among others that more attention should be paid to the provision of adequate incentives as well as training and development on contemporary issues in tax management for tax officers to promote their efficiency and effectiveness in developing economies including Nigeria. Furthermore, since citizens' expectation on societal general development and demand varies across various divisions and localities in Lagos State, the state government should, therefore, accommodate the aspirations of the various groups to engender sustainable tax compliance by citizens.
\end{abstract}

Keywords: Balanced Scorecard, Performance Measurement, Productivity Improvement, and Public Agency.

JEL codes: $H 20, H 21, H 71$

\section{INTRODUCTION}

All over the world, governments have adopted an array of instruments targeted at public institutions, public managers, citizens, and institutional research partners to accomplish improved public agency performance for productivity and sustainability through performance. Performance is a relative concept connected with the phenomenon being studied (Hofer \& Carton 2006). Performance is a multidimensional construct and overwhelmingly contested with various intellectual perception as viewpoints, periods and criteria are investigated differently (Dinçer, Yükse, Korsakiene, Raišiene \& Bilan, 2019). Abuhashesh, Al-Dmour and Masa'deh (2019) agreed that performance stem and is associated with reinforcement to achieve the overall target goal. Performance is a broad concept: it has a choice of meaning for different audiences and diverse contexts (Carter, 1991). Performance must be defined, to measure or manage it (Armstrong \& Baron, 1998). Understanding context of the phenomenon of performance in public arena, Wouter (2006) contended that performance is synonymous with reform in public sector aimed at higher performance leading to a better economy, efficiency, effectiveness, equity and ethical relation inevitably leading to performance measurement. Fisher (2019) argued that the need for organizing principle of alignment and specific application and transfer as performance indicators permeate everyday life of public and private sector. Lewis (2015) sees performance measurement as a social structure hinged on a sequence of measurement - a set of interactions with outputsconsequences, which generate a set of corrections in line with unanticipated and undesirable effects. Further, it is not a production model, but about institutions, individuals, interactions and each interrelatedness.

Political policy is the foundational formation for performance measure engulfed with a price and visible consequence. It gains more attention with New Public Management (NPM) with concern for measurement and more management as citizens begin to actively ask a question on institutional performance as they should.

http://dx.doi.org/ 10.30585/jrems.v1i3.347

(C) 2019 the Authors. Production and hosting by Avicenna FZ LLC. on behalf of Dubai Business School, University of Dubai UAE. This is an open-access article under the CC BY 4.0 license (https://creativecommons.org/licenses/by/4.0/). 
Citizens are more passionately apprehensive about the expenditure on public finances (Radin, 2006). Numerous factors have been established for performance measurement and reasons why public managers measure performance, Behn (2003) opined that we measure performance to evaluate, control, budget, motivate, promote, celebrate, learn, and improve. Performance measurement is seen as an end in itself, its major rationale is to produce measures (Schick, 2001). It implies that three key premises involved in performance measurement are interaction, institution, and citizens. A key factor amidst the hallmarks of PM is to gain insight into and make verdict pertinently on the organization either public or private owned exclusively for effectiveness and efficiency of its programs, processes, and people solely to demonstrate progress with measures (Jääskeläinen \& Lönnqvist, 2011).

Performance measurement is systemically interlinked. It encompasses policymakers, stakeholders, leadership, management capacity and capability, employee commitment and goal clarification with appropriate modus operandi which lead to the better sustainable performance of (MDAs-Ministries Department and Agencies) organization to attain efficiency and effectiveness of identified goals. Kelly et al. (2002) classify values created in the public sector to include services, social outcomes, and trust. Services denote, amplified efficiency, better quality, user's satisfaction, more patronage of services, greater equity (fairness) in service provision. Social outcomes, on the other hand, implies social cohesion, equality, wealth distribution, safety, poverty reduction, better-educated population, improved health, which represent the central aims of public services. Trust is aligned with legitimacy which gives societal members a level of satisfactory acceptance of policy accomplishment broadly. A Public sector provides services mainly at cost-effectively and creates societal good, value multifaceted thus value is harder to measure (Mulgan \& Albury, 2003; Kelly et al., 2002, Bloch \& Bugge, 2013).

To explore new methods of performance measurement, Kaplan and Norton in 1990 led new research to add another form of creating value and developed Balanced Scorecard (Išoraitè, 2008). Muiruri \& Kilika (2015) opined that Balanced Scorecard (BSC) is used strategically in business, industry, government and nonprofit organizations worldwide to ally business actions to the vision and strategy of organizations. It is meant to improve more internal and external communications and monitor organizations' performance against strategic goals. Kaplan \& Norton (1992) introduced the new tool as balance scorecard which captures activities of customer's issues, internal business process, and employee and stakeholders' concerns. It was a tool for an organization to manage the demand of relevant stakeholders and to convert it into strategy through integration with consideration of four (financial perspective, customer perspective, internal perspective, and learning perspective) framework for a balanced scorecard.

The public sector's productivity is a complex and multidimensional with various performance measurement system explored, these include; Benchmarking, Continuous Improvement, Management by Objectives (MBO), Quality Control Circle (QCC) and Key Performance Indicators (KPIs), Critical Success Factors (CSF) ActivityBased Costing/Management (ABC/M), Benchmarking, Total Quality Management (TQM), Business Process Reengineering (BPR) and Balanced Scorecard (BSC) (Zakaria, 2011 and Ruzita Kaveh Asiaei, Ruzita, 2014). Išoraitè (2008) however, maintained that balanced scorecard is a management system that transforms the vision, strategy and creates a feedback mechanism for internal process and outcomes to persistently improve operational efficiency.

Visionary agenda for Lagos State is designed towards Africa's model megacity and global economic and financial hub that is safe, secure, functional and productive. It is a cosmopolitan city rated the 9th most populated city in the world with about 22 million populations and accounted for $60 \%$ of Nigeria industrial investment, foreign trade, and commercial activities, approximately $40 \%$ with GDP of $\$ 150 \mathrm{bn}$ per annum. (LCCI, 2015). Lagos State encounter with the challenges that accompanied staggering population, expansion rates, and resilience cities from a crumbling metropolis into a modern, attractive, and purposeful city through financial meticulousness on her internally generated revenue aided by constancy vis-a-vis consistency on general blueprint followed by each elected leaders. Public agencies' manager worldwide face the accountability-related challenge to adequately manage cost and are on a pursuit to attain increased economy, efficiency, and effectiveness in service delivery (Dixon et al., 1996, Dixon, Kouzmin \& Korac-kakabadse 1998, Ho \& Kidwell 2000, Biswanath, 2007).

The pursuit for responsive and consensus-oriented outcome in service delivery and non-reliance on federal allocation prompt the state government looks inward the way of revenue. Through strategic visioning for development, political leaders and the public were able to take deliberate broad long-term human development initiatives as well as envisage plan on the resources required for its accomplishment are devised. Lagos state government commence with strategic initiative of Tax Payer Education and Enlightenment, as a foremost step the state organized a Taxation Stakeholders' Conference in 2007 which was interactive in nature and forum for the State Executive Council to discuss with representative of the Chamber of Commerce, professional groups, financial institution, traditional rulers and market associations e.t.c. The theme of the conference concerned 
government expectation from them, various means and efforts to radically reform revenue administration in the state. The conference grants feedback on comments, suggestion, and ideas from the stakeholders' interactive platform. It is instructive to note that Taxation Stakeholders' Conference has since become an annual event of the Lagos state government. (Asaolu, Dopemu \& Monday, 2015). Lagos State Internal Revenue Service (LIRS) is the major revenue-generating public agency of Lagos state since it was set up in 2006 with a strategic measure from an average of 600million in 1999 to 436billion in 2016.

\subsection{Statement of the Research Problem}

In the 1990s, the Lagos State Board of Internal Revenue (LSBIR) unproductive due to the peculiarity of Nigeria federalism. The increased level of interest on improving performance measurement in government since the late 1980s championed by the new public management movement and the central planks of the "reinventing government" movement (Osborne \& Gaebler, 1992, Ruzita, Azhar \& Abuhasan 2012). Before democratic rule in 1999, one major issue associated with Lagos State was that fund collected on tax within the state was minimal most especially during the military rule in the country. Following the return to civil rule in 1999, Lagos State Government engaged private sector consultants to assist in tax administration aiming at appropriate taxation policy. Egbonike, Emudainohwo \& Gunardi (2018) contended that tax revenue mobilization as a financial source of development is difficult due to various forms of resistance; evasion, avoidance, and corrupt practices which is part of the reasons for underdevelopment in Nigeria (Abata, 2014). Blessing, Endurance \& Stephanie (2017) sited Gregory (2008) on his part argued that despite the improvement in the tax system, certain issues require urgent attention.

The democratically elected government engaged consultants to gathered database and information on taxable individual and organization in Lagos. Simon, Simon \& Robert (2017) opined that tax administration is challenging in developing economies due to a high level of illiteracy, low level of awareness and insufficient orientation. Blessing, Endurance \& Stephanie (2017) maintained that scarcity of database contributed to tax avoidance. Also, poor naming of streets in major cities like Lagos has made it difficult to locate taxpayers. Apart from this, a large part of the population is poor under-employed and unemployed without visible income. All these factors are militating against effective tax administration in the state. It must be emphasized that public service delivery in Lagos requires huge financial investment because Lagos used to be the nation's capital territory, however, it lacks adequate federal funding. To meet the need of the citizens in terms of provision of infrastructural facilities, adequate revenue must be generated within the state.

Revenue generation drive in Lagos State began in early 2005 when the government highlighted tax as an area of vital importance to Lagos State. Currently, the LSBIR was exploitative and impose arbitrary levies on the residents without a standard of measurement. Citizens without knowledge of tax law were cheated by deceitful personnel. Balanced Scorecard (BSC) was however initiated to review organization performance for a certain period. (Su \& Baird, 2017; Micheli \& Mura, 2017, Sonson, Kulatunga \& Pathirage 2017). BSC is a high-quality instrument in the framework of public organizations (Chang, 2006; Niven, 2003; Quinlivan, 2000; Fletcher \& Smith, 2004). This study seeks to examine the extent to which BSC is used to improve the performance of public agency specifically LIRS in Lagos state, Nigeria

\subsection{Objectives of the Study}

The main objective of this study is to examine public agency performance measurement using balanced scorecard (BSC) with specific reference to Lagos State Internal Revenue Services. Other specific objectives are to:

1. Find out the extent which financial perspectives effective public agency productivity.

2. Examine the extent to which learning and development aid productivity in LIRS.

3. Evaluate how customers perspective affects the profitability of LIRS.

4. Investigate how internal perspectives bring about efficient service delivery

\subsection{Research Questions}

1. How does of financial perspective affect public perspective productivity?

2. To what extent development and learning perspective influence productivity?

3. What is the nature of the relationship between customers perspective and profitability?

4. Is there any relationship between internal perspectives and efficient service delivery 


\subsection{Research Hypotheses}

The hypotheses are stated in null form:

1. That there is no relationship between financial perspective and agency productivity.

2. That development and learning perspective does not affect agency productivity.

3. That there is no significant relationship between customers' perspective and profitability.

4. That internal perspective and efficient service delivery do not have any correlation.

\section{LITERATURE REVIEW}

Performance is a multi-dimensional construct and overwhelmingly debated with various intellectual background perceptions. Meaning of Performance measurement differs, depending on a variety of factors that encompass it (Fitzgerald \& Moon, 1996). Public agency performance-critical concerns on expenditure (Lewis, 2015). Performance is about work and results achieved (Otley, 1999). Gibson, Ivancevich, Donelly, \& Konopaske (2012) posited that performance is geared towards organizational goals that include; service quality, efficiency, and related effectiveness criteria to achieve a result. Edis (1995) argued that performance is something that the person leaves behind and that exists apart from the purpose. Mwita (2000) contended that performance is an interrelated variable of three: behaviors (processes), outputs, and outcomes (value-added or impact) through which designed objectives are achieved. On behavioral viewpoint on, Colquitt, Le, Pine \& Wesson (2011) added three dimensions to performance, that; task is performed, during which voluntary behavior cum positive behavior and negative behavior (counterproductive) that occurred. Performance agenda is a new business technique in the public sector with a prototype change-oriented on entrepreneurial government (Osbourne \& Gaebler, 1993).

This paper posited performance as an interrelated strategic act that embraces an entrepreneurial government that considered human behaviors, output, and outcome concerning organization goals. Performance cannot be attained without a certain attribute that affects it. Armstrong \& Baron (1998) \& Mwita (2000) argued that performance factors include; Personnel, Leadership, Team, System, and Contextual (situational) factors which are crucial when measuring, modifying and rewarding performance.

\subsection{Performance Measurement in the Public Sector}

There is no universally accepted definition for the term performance management. Researchers and scholars defined it from; features, role and the process of focus. (Hasan, 2018). What gets measured, get managed (Schmennar \& Vollmann, 1994; Ibrahim \& Muritala, 2015). Lewis (2015) asserted that performance measurement is a political utilization of data collected and used to exhibit effectiveness against a set of criteria that serve as standard gauge for firms, employee and managers for best practices to achieve optimally for better service. Hamri, Asmawi \& Rasyid (2019) performance must consistently be improved to produce equality. Supporting this notion, Radin (2006) argued that performance measurement commenced to eliminate a program, chant a new path and it is aimed at making the best use of tax income in a transparent way to the public. Historical evolution of performance measurement passed four phases; efficiency, result, quality and integrate era (Hassan, 2018). The efficiency period (1900-1920s) entails the design, make and sell industrial efficiency of tailor concept. (Gould, Bourk \& Joullié, 2017, Hassan 2018). The resulting phase (1920s-1950s) entails the Return on Equity (ROE), maximizing profit, financial leverage and asset efficiency leading to the introduction of DuPont formula as benchmark analysis metrics. (Yadav \& Sagar, 2013). The quality phase (1960s-1990s) engulf sufficient information for building a resilient system and unique experience encouraging creativity. This era is characterized by; goal setting. Linking Activities with Goals, Variance Analysis, Key Performance Indicators and Inclusion of Nonfinancial Indicators. (Hassan, 2018). Lastly, the integrated era (1990s-date) comprises of Kaplan and Norton four indicators of balanced scorecard to a strategic outcome.

Performance measurement implies calculated advancement towards pre-arranged goals, with the availability of adequate data efficiently to transform human and material capital into required goods and services for suitable citizenry acceptability. While the notion of measuring the performance of the public sector was certainly existing before NPM, its arrival limited the attention of performance to the deliberation of the result, with less consideration for how these are achieved (Van Dooren, Bouckaert, \& Halligan, 2010, Lewis, 2015). Performance measurement is not alien to the public sector, rather, it becomes intensive with reform agitation pushed regarding public management (Pollitt \& Bouckaert, 2011). Schick (2001) claimed that performance measurement has to turn out to be an end, its main rationale being to produce more standardized measures. It is symbolic not only to be undertaken as a goal in itself but a designated policy and organizational rationality (Lewis, 2015). Although the system involves measuring performance in the public sector, certain inherent 
barriers are associated with it as most governments based it on efficiency, effectiveness and economy indicators that are predicated on finance but failed to measure the fulfillment of social and environmental goals of the public institution. Chai \& Dung (2009) realigned the "3 Es" (Efficiency, Effectiveness, and Economy) to a "5 Es" (Economy, Efficiency, Effectiveness, Environmental and Equity) because a public organization exists ecologically. Generally, public sector entails requisite of a relationship between objectives, means, and results but the distinctiveness of peculiar bane embedded in process and procedure varies from nations to nation. Stefanescu et al (2010) identified causes of the complexity of measuring performance in the public sector which include: typology of public sector entities; diversity of perception of performance; complexity of the economicsocial environment; ascendant trend of consumers; discrepancy between the number of consumers and the one of contributors towards the establishment of public resources; managers' low interest for identifying new financing sources; real non-existence of the correlation financial performance - non-financial performance, respectively the influence of the political system. This implies that all public institutions irrespective of category, require a comprehensible and cohesive performance measurement framework at all levels of the organization that supports objectives within the realm of their goals clearly stated for the workforce.

\subsection{Public Agency and Improving Public Service}

Administration of public institutions is based on structure and system irrespective of the system of operation adopted. Ministries, Departments, and Agencies (MDAs) serve as platforms for the realization of the policies. Laking (2005) contended that agencies are organizations which are not within the typical government and not integrated institution. Agencies are outside the mainstream of government and have internal modalities but work with germane related rules. OECD (2002) identifies three types of organization that can be differentiated from core government and that are not in a vertically integrated hierarchical relationship with core government organizations namely; Departmental Agencies which are core part of ministries with same legal identity, but their internal management is different, and generally operate separately when compared to their parent ministry. Public law administration is established with the public statute, possessed legal identity under public law at times have a board of directors. Private law bodies are under the direct control of ministers and have a governing board. Furthermore, Talbot et al. (2000) identified five agencies in developing and transition economies. These include:

Parastatals: These are business enterprises, corporatized or privatized fully in line with corporate governance rules.

AGETIPS: These are mostly francophone organizations, non-profit in nature for implementing public works.

Social funds: These are designed to finance a variety of projects meant to drastically reduce poverty alleviation sometimes called "social investment funds"

Extra-budgetary fund administrations: examples are pension funds, health insurance funds, agricultural subsidy funds, etc.

Independent revenue authorities (IRAs): These are agencies charged with tax collection and administration within general tax policy. According to World Bank (2002), Independent revenue authorities (IRAs) are independent agencies that have a workforce, provide motivation and thoroughly scrutinized of performance. The LIRS fall within the (IRAs) agency charged with tax collection and administration created by statutory law in 2007. Public service aims at improved social welfare standard for all citizens through service rendered with enhances productivity.

Productivity should not be considered anymore as a possibility, but as an imperative in the current world context, it can be defined as the rate in which products are generated in terms of units of any of these inputs: labor, capital, land and time (Sánchez \& Toharia 2000). Productivity is defined mostly as a measurement of the amount of output generated per unit of input. In many countries, including Nigeria, public sector productivity has been assumed to be zero in the national accounts. The output of the government sector has been measured as of value equal to the total value of inputs. The challenge is to devise alternative estimates based on output measurement, in a public sector context where there is a provision of collective services and where there is no market transaction in services provided to individuals in most instances. A problem that is generally considered to be the only sustainable way of improving living standards in the long-term.

\subsection{The Balanced Scorecard and adaptation in LIRS at a Glance}

Quesado, Guzmán \& Rodrigues (2018) empirically showed that leading companies unquestionably adopted BSC after series of verification that it improves performance, help to meet stakeholder expectation and evaluate implementation strategy. The conceptualization of BSC instituted with the private sector mindset and was advocated from both theoretical and practical understanding (Olve, Roy \& Wetter, 1999). The BSC framework 
emphasizes that the financial objectives and more limelight on other the component of performance. These other features of BSC have attracted government and public sector enterprises which have to meet performance management purpose (Aidemark, 2001; Bilkhu-Thompson, 2003; Modell, 2004).

There is upward substantiation on its appropriateness and relevance in the not-for-profit sector, especially the government sector (Atkinson \& Mc Crindell, 1997; Kloot \& Martin, 2000; Bolívar et al 2010). Furthermore, BSC utilization and outcome in public services likes hospital and healthcare services (Aidemark, 2001; Amaratunga, Haigh, Sarshar, \& Baldry, 2002; Chan \& Ho, 2000; Chow, Ganulin, Haddad, \& Williamson, 1998; Protti, 2002), police services (Elefalk, 2001) and tertiary education (Chang \& Chow, 1999; Stewart \& Carpenter-Hubin, 2001). Wilson, Hagarty \& Gauthier (2003) analyzed the use of BSC in public organizations in different countries and concluded that the BSC approach has proven to be a well-accepted management practice. In the $21 \mathrm{st}$ century, the public sector has advanced from an information method based on financial measures to another broader-based to promote the future success of the organization (Hoque, 2005).

The Balanced Scorecard was conceptualized by Robert Kaplan \& David Norton (1992) to formerly shape measurement system and as a reaction to criticism about the one-sided measurement of the performance capability of a company on financial portion. The crux of the study was on the increase opinion that fiscal measures of performance not sufficient for the contemporary company. (Išoraitè, 2008). Possible alternatives were examined but the team established on the proposal of a scorecard, distinguishing performance measures and consider other activities in the organization; customer related-issues, internal business processes, employee activities in the organization and shareholders disposition. While there are many reasons for measuring the performance of an organization performance measure of an organization remains validly imperative as stakeholders need to know whether or not the organization is fulfilling its purpose (Etim \& Agara 2011).

Kaplan \& Norton position the Balanced Scorecard as a tool for organizations to manage the demands of all relevant stakeholders and to translate strategies into action. The BSC serves as an indicator to identify two crucial guides: that focuses on the feat of a strategic target in the outlook (provided meter) as well as results (underprovided meter) to depict the effectiveness and efficiency of measurement. Research antecedent revealed that BSC has been adopted for long -term strategy, and possessed two main classified advantages. Organizational strategy level and strategic alignment level. The former involved; communication, implementation, strategic objectives, deployment of indicators that capture both financial and non-financial perspectives. The later contained enabling the tangible link of a mission, boost employee morale, integration of all level within the organization for common goal through the existence of harmonies relationship between decision, action, and outcomes. (Quesado, Guzmán \& Rodrigues 2018)

\subsection{Different Perspectives of Balanced Score Card}

Different perspectives of BSC can be identified viz:

Financial perspective: Financially, how should our shareholders identify with us in term finance data management? It entails satisfactory fund, prudent utilization of fund and record for proper audit and measurement against cash flow. More often there is more than enough handling and processing of financial data.

Customer perspective: Vision wise, how our appearance aligned with our customers? Modern management ideology has shown an increasing realization of the importance of customer focus and customer satisfaction in any government policy as citizens are more aware and demand better satisfaction on governance provided citizens are not satisfied, a human is bound to locate another solution provider. (Kaplan \& Norton, 1997, Isoraite 2008).

Internal perspective: Expectation wise of our shareholders, clients and customers, what aspect must stand out and be improved on. This improvement would change the outlook of services when more grey areas are strategically re-defined for efficiency in output.

Learning and Growth perspective: This perspective engulfs and encompasses employee training both individual and corporate self-improvement in an organized strategy. Training and organizational attitudes related to both employee and organizational enhancement on learning and growth structure create the groundwork for the accomplishment of an organization (Kaplan \& Norton, 1997, and Isoraite 2008).

Hristov, Chirico \& Appolloni (2019) contend that BSC identifies, integrate and assist in improving financial and non-financial business objectives simultaneously for management. The balanced scorecard is an agenda for setting an organization's strategic intention into a laydown blueprint of performance pointer within the BSC framework. With BSC, the organization keeps an eye on both its present performance and steps embarked on 
to progress, inspire and enlighten employees, and enhance information coordination. BSC adoption principally entails premeditated sustainable and long-term dedication to make an organization effective. The severe decline in the price of crude oil in the international market, no doubt has affected finance availability for distribution at the national level in Nigeria. This development, no doubt, encourages other tiers mostly state generate revenue from internal sources (Dennis \& Emmanuel, 2014). Aguolu (2004) states that though taxation contribution to state resources seems minimal, to the government, it is the most certain, and consistent source of revenue. This assertion is partly not out of place as LIRS has to be one of the most important sources of revenue that is consistent, certain and commendable with each year's revenue from taxation surpassing the previous ones in Lagos State.

Lagos State Internal Revenue Service (LIRS) is the revenue agency of the Lagos State Government engaged with the task of collecting taxes. The LIRS aims to make Lagos State take away its focus from resources accruing to the tiers of government from the Federal Government. The agency has a blueprint on the tax system and executes a self-sustained income format to guarantee citizens compliance. The Lagos state government begins to identify the necessity of financial independence, after a long battle between the state and the federal government over revenue withheld by the federal government during President Obasanjo's era. It has become apparent that the state has to strive to survive through revenue generated from taxation. In line with the management's policy of taxpayers' engagement, LIRS has hosted the annual Lagos State Taxation Stakeholders' Conference ever since 2007. The conference provides a forum for the Executive Governor of Lagos State and His Executive Council to converse with representatives of the Chambers of Commerce, professional groups, financial institutions, traditional rulers, and trade \& market associations, etc. on the various means and efforts to reform tax administration. It must be emphasized that the state government has declared that only 600,000 people pay taxes while over 3.5 million people evade taxes in Lagos State. (https://lagosstate.gov.ng).

Situating the above four balanced scorecard balanced tenets within the context of Lagos state tax administration, the following can be observed;

Financial perspective: The state government established LIRS, make it autonomous and self-accounting in January 2006 by passing it into law. Lagos is the most financially viable in terms of revenue generation in the federation.

Customer's perspective: A customer wants value for their commitment, this brings about the initiative on tax education and yearly tax conference of stakeholders where input is required to service the society at large better.

Internal perspective: The process of efficiency and effectiveness are germane, their regular training, once in a week board discussion to discuss feedback from an agency employee and the employees enjoy 13-month salaries to promote efficiency in service delivery.

Innovation and learning perspectives: There are series of technologically driven measure put in place for the citizenry which includes; online payment as well as online self-assessment tailored towards customer's suitability and comfortability.

\subsection{Theoretical Framework}

This paper is situated within the context of Theory of Change (ToC). Change procedure provides consideration to inputs, processes, outputs, goals, assessment, and evaluation, and learning. In its early conceptualization, Weiss (1995) described Theory of Change (ToC) as "a theory of how and why an initiative works". James (2001) ToC has been developed following two different fields: evaluation processes and part of social change theories. ToC emerged as a need to concentrate on poor evaluation practices which were not able to satisfactorily deal with the complexity of initiatives (Center for ToC, 2013) According to Clark \& Anderson (2004), ToC is a mini-steps that lead to a durable goal and the link connecting activities to the outcomes of a program.

In the view of Vogel (2012), there is no single definition of what theory of change is and no set methodology. Irma (2018) also argued that Theory of Change is considered from many perspectives: as an approach, a tool, a methodology, a planning methodology, a strategic planning process, and a product. Terminologies associated with ToC include; a pathway of change (Anderson, 2005), the roadmap (Taplin et al., 2013) a blueprint, an engine of change, a theory of action and more. (Stein \& Valter, 2012). Stein and Valters (2012) argued that numerous organizations are more contented on $\mathrm{ToC}$ as a variant of the 'logic model and sum up ToC through simple "if...then" statements. Collaborating this position, CARE (2012) opined that if there is constructive engagement among key stakeholders on political economy issues, then it will improve information flow and 
lead to a shift in policy and decision making. Moreover, Stein and Valters (2012) categorized the purpose of the theory of change into four which include;

Strategic planning: This entails understanding process and outcome for project execution by adopting a log frame model.

Monitoring and evaluation: This is concerned with a review and revises outcome for assessment of an organization

Description: This focuses on internal and external associate with medium to relate for better engagement.

Learning: This aims at making ToC as a thinking tool for developing a model for action.

Retolaza (2011) affirmed that ToC provides a practitioner with a prospect to connect more openly with the intricacy of revolutionizing procedure. These practitioners' in the view of Shapiro (2006) include:

Changing individuals: (involve an approach that modifies stance and insight, sentiment, manners and encourages partaker in an intervention) the state through the tax conference in 2007 begin to harness and explain the citizen's expectation on tax revenue.

Programs that center on altering relationships (entails a new set of connections, partnership, treaty, and other supportive bonds between members of conflicting groups to fostering social changes that help resolve contending issues). Various contending issues are resolved through the conference as a relationship between the state, actors, towards better societal change.

Structural, institutional and systemic changes are the crucial focus for some variance programs (entails efforts made often directly aimed at legislative, electoral and judicial reform, establishing new mediating mechanisms and forums within society, economic development initiative). The State restructured LSBIRS to LIRS, with legislative backing spread across the five-division of Lagos for efficiency and effectiveness.'

The state existence hinged on many interrelated, interdependent and inextricably intertwined boundary aimed at positive change in the society. The change process requires various actors and stakeholders to contribute objectively towards a better society coupled with a model to attain organizational vision and strategy. This implies that the state government understands that in achieving sustainable revenue generation, the stakeholder is a means to an end and not an end in itself. The tax conference of 2007 sows the seed of all input exchanging materials with its information flow. All ideas, contributions, demand, expectation, and yearning of the citizenry of Lagos state aid policy shift and decision making towards a better robust revenue drive. It is a mini-step that define a long-term goal of viable revenue agency, a pathway of change (Anderson, 2005), the roadmap (Taplin et al., 2013), a blueprint, an engine of change, a theory of action and more. (Stein \& Valter, 2012).

\subsection{Empirical Review}

BSC is one of the most broadly used tools by executive worldwide, the research on the BSC cut across different fields; hospitality and tourism, education, health sector accounting and management and public sector service (Trotta, Cardamone, Cavallaro, \& Mauro, 2012; Sayed, 2013, Dreveton, 2013; Madsen, 2015; Palatková, 2015). Also, Quesado, Guzmán and Rodrigues (2012) in their empirical research situated in the context of theories of contingencies and institutional model, to reveal advantages derived from the implementation of the BSC in Portuguese public organizations precisely area of the borough, health and /inter-municipal business. The outcome of the study revealed that $91.7 \%$ of respondents explained that BSC facilitated the implementation of the strategy and has a positive influence on the development of more strategies. It prompted enhancement in organizational performance (83.3\%), promote lucid communication of the strategy $(75 \%)$.

Furthermore, Quesado, Aibar \& Lima (2018) identify and analyses effect derived from BSC execution, their findings include; that the BSC has these tasks; performance appraisal system, transform the mission and organizational tactic, support more feasible means of communication procedure, the strategic alignment and improve overall organizational learning. Bhagwat and Sharma (2007) also researched three case studies in India, the outcome established that BSC helps internal and external function better with wider monitoring of organization business. 
Hoque \& James (2000), in a study conducted in 66 Australian industrialized corporations, concluded that the BSC promotes the advancement of organizational performance. Muiruri \& Kilika (2015) collaborated the Hoque \& James in their study on some selected public sector organizations in Kenya relating to the BSC on Performance of Public sector and four BSC perspective in Kenya. The findings revealed that $71 \%$ difference in performance is ascribed to the BSC as a tool for use in strategic management is relevant for application in the public sector, however, its comparatively low score on innovation due to the widespread bureaucratic cultural surroundings of the sector.

\section{METHODS}

\subsection{Research Design}

This study adopted a qualitative approach using primary data obtained through self-administered questionnaires To the respondents.

\subsection{Sample and Methods of Data Collection}

The population of the study comprised all tax stations in Lagos State spread across the 20 Local Government Areas (LGAs) and 37 Local Council Development Areas (LCDAs). There are one thousand, four and one $(1,401)$ employees working in the fifty-seven (57) LGAs\& LCDAs in Lagos state. Using Yamane's (1973) sampling formula for sample size determination, a sample size of 40 tax stations and 302 employees were selected using simple random sampling and stratified random sampling techniques respectively. The sample size formula is given as:

$$
n=N /\left(1+N(e)^{2}\right) \text {, }
$$

where: $\mathrm{n}=$ sample size, $\mathrm{N}=$ population size, and $\mathrm{e}=$ error term (minimum margin error $5 \%$ ). Determination of sampled tax stations in Lagos state given that $\mathrm{N}=57$, and $\mathrm{e}=0.05 . \mathrm{n}=57 /\left[1+57(0.05)^{2}\right]=49$ Tax Stations, Determination of sampled employees working in tax stations in Lagos state given that $\mathrm{N}=1201, \mathrm{e}=0.05, \mathrm{n}=$ $1401 /\left[1+1401(0.05)^{2}\right]=300$ Respondents,

Three hundred (300) copies of the questionnaire were administered to selected respondents in the selected forty (40) tax stations in Lagos state. The area was chosen because the researcher anticipated that it will provide all the necessary information for the study. The results were presented in simple visual forms using tables. The regression and correlation tools of analysis were used to show how the public agency performs using balanced scorecard in Lagos State Internal Revenue Service (LIRS).

\subsection{Reliability}

Cronbach's alpha coefficient of reliability was calculated for six (6) major constructs. The results show that the research instrument reliable and internally consistent since the Cronbach's Alpha result for all the construct is greater than 0.7. The result of the pilot study indicates a high level of internal consistency for seven (7) constructs: Financial Perspective (0.749), Development and Learning Perspective (0.824), Customers' Perspective (0.776), Internal Perspective (0.862), Productivity (0.777), Profitability (0.810) and Efficient Service Delivery (0.910). The benchmark for reliability Cronbach's Alpha score is .70 as recommended by Nunnally (1978). Thus, all the constructs have above the minimal 0.70 ; therefore, the overall reliability of the scale is guaranteed.

\section{ANALYSIS AND RESULTS}

The information retrieved from the questionnaires revealed that Two hundred and twelve (212) copies of the questionnaire were fully completed which gives a $71 \%$ response rate. Majority of the respondents are male, single with BSC/HND qualifications within the age range of 30-39 years and 5- 10 years of job experience. This implies that the agency considers goal attainment in the selection of its workforce as it picks the active workforce.

In this section, an attempt is made to test the stated hypotheses using Pearson Product Moment Correlation Coefficient and Regression Analysis 


\section{Hypothesis one}

There is no relationship between financial perspective and agency productivity.

Pearson Product Moment Correlation was used to test this hypothesis.

Table 1. Correlations

\begin{tabular}{cccc}
\hline & & FINANCIAL PERSPECTIVE & PRODUCTIVITY \\
\hline \multirow{2}{*}{ FINANCIAL PERSPECTIVE } & Pearson Correlation & 1 & $.850^{*}$ \\
& Sig. (2-tailed) & & .029 \\
& N & 212 & 212 \\
PRODUCTIVITY & Pearson Correlation & $.850^{*}$ & 1 \\
& Sig. (2-tailed) & .029 & 212 \\
\hline
\end{tabular}

${ }^{*}$ Correlation is significant at the 0.05 level (2-tailed).

The Pearson Product Moment Correlation Coefficient result suggests that there is a positive relationship between financial perspective and productivity $(r=0.852)$. This relationship is statistically significant because the $p$-value for the result $(0.029)$ is less than the level of significant $(0.05)$ used for the study. This suggests that the financial perspective is related to productivity positively and significantly.

\section{Decision:}

The null hypothesis was rejected, while the alternative hypothesis was accepted. This implies that there is a significant positive relationship between financial perspective and agency productivity.

\section{Hypothesis two}

Development and learning perspective does not affect agency productivity.

Regression analysis was used to show the extent to which development and learning perspective affects agency productivity at a $5 \%$ level of significance. The results are as presented in Tables 3 to 5 showing the regression model summary, ANOVA and the regression coefficients respectively.

Table 2. Model Summary

\begin{tabular}{ccccc}
\hline Model & $\mathrm{R}$ & $\mathrm{R}$ Square & Adjusted R Square & Std. An error of the Estimate \\
\hline 1 & $.920^{\mathrm{a}}$ & .846 & .844 & .035
\end{tabular}

a. Predictors: (Constant), Learning Perspective

The model summary in table 3 shows that the coefficient of determination (R-square) is 0.846 . This means that $84.6 \%$ of the variance recorded in productivity is accounted for by development and learning perspective. The result is statistically significant because the $p$-value for the result $(0.000)$ is less than the level of significant (0.05)

Table 3. ANOVA

\begin{tabular}{ccccccc}
\hline & Model & Sum of Squares & Df & Mean Square & $\mathrm{F}$ & Sig. \\
\hline \multirow{2}{*}{1} & Regression & 34.156 & 1 & 34.156 & 64.766 & $.003^{\mathrm{b}}$ \\
& Residual & 110.746 & 210 & 0.519 & & \\
& Total & 144.902 & 211 & & & \\
\hline
\end{tabular}

a. Dependent Variable: Productivity

b. Predictors: (Constant), Learning Perspective

Table 3 shows that the model used has a good fit since the calculated $F$ ratio of 64.766 is greater than the tabulated $F$ ratio value of $3.00\left(F_{1,210}=3.00\right)$.

Table 4. Coefficients

\begin{tabular}{|c|c|c|c|c|c|c|}
\hline \multirow{2}{*}{\multicolumn{2}{|c|}{ Model }} & \multicolumn{2}{|c|}{$\begin{array}{l}\text { Unstandardized } \\
\text { Coefficients }\end{array}$} & \multirow{2}{*}{$\begin{array}{c}\begin{array}{c}\text { Standardized } \\
\text { Coefficients }\end{array} \\
\text { Beta } \\
\end{array}$} & \multirow[t]{2}{*}{$t$} & \multirow[t]{2}{*}{ Sig. } \\
\hline & & B & Std. Error & & & \\
\hline \multirow{2}{*}{1} & (Constant) & 3.664 & .037 & & 2.991 & .000 \\
\hline & Learning Perspective & 0.17 & .009 & .119 & 1.744 & .003 \\
\hline
\end{tabular}

a. Dependent Variable: Productivity

The simple regression model is given as:

$$
P=3.664+0.17 L P .
$$


An evaluation of the unstandardized coefficient of learning perspective in the coefficient table and its associated $p$-value $(\beta \mathrm{LP}=0.17, p<0.05)$ shows that learning perspective is statistically significant and can be used in predicting productivity. This signifies that for every unit increase in a learning perspective, productivity is increased by 17 percent.

\section{Decision:}

The null hypothesis is rejected while the alternative hypothesis is accepted. This means development and learning perspective affects agency productivity significantly.

\section{Hypothesis three}

There is no significant relationship between customers' perspective and profitability.

Pearson Product Moment Correlation was used to test this hypothesis.

Table 5. Correlations

\begin{tabular}{llcc}
\hline & & Consumer Perspective Profitability \\
\hline \multirow{2}{*}{ Consumer Perspective } & Pearson Correlation & 1 & $0.862^{* *}$ \\
& Sig. (2-tailed) & & 0.000 \\
Profitability & $\mathrm{N}$ & 212 & 212 \\
& Pearson Correlation & $0.862^{* *}$ & 1 \\
& Sig. (2-tailed) & 0.000 & 212 \\
\hline
\end{tabular}

${ }^{\star \star}$. Correlation is significant at the 0.01 level (2-tailed).

The Pearson Product Moment Correlation Coefficient result suggests that there is a positive relationship between consumer perspective and profitability $(r=0.862)$. This relationship is statistically significant because the $p$-value for the result $(0.000)$ is less than the level of significant $(0.05)$ used for the study. This suggests that the consumer perspective is related to profitability positively and significantly.

\section{Decision}

The null hypothesis was rejected, while the alternative hypothesis was accepted. This implies that there is a significant positive relationship between customers' perspective and profitability.

\section{Hypothesis four}

Internal perspective and efficient service delivery do not have any correlation.

Pearson Product Moment Correlation was used to test this hypothesis.

Table 6. Correlations

\begin{tabular}{cccc}
\hline & & Internal Perspective Efficiency in Service Delivery \\
\hline & Pearson Correlation & 1 & $0.731^{* *}$ \\
Internal Perspective & Sig. (2-tailed) & & 0.000 \\
& $N$ & 212 & 212 \\
& Pearson Correlation & $0.731^{* *}$ & 1 \\
Efficiency in Service Delivery & Sig. (2-tailed) & 0.000 & 212 \\
& $\mathrm{~N}$ & 212 & 212 \\
\hline
\end{tabular}

**. Correlation is significant at the 0.01 level (2-tailed).

The Pearson Product Moment Correlation Coefficient result suggests that there is a positive relationship between internal perspective and efficient service delivery $(r=0.731)$. This relationship is statistically significant because the $p$-value for the result $(0.000)$ is less than the level of significant $(0.05)$ used for the study. This suggests that the internal perspective correlates with efficient service delivery significantly

\section{Decision}

The null hypothesis was rejected, while the alternative hypothesis was accepted. This implies that there is a significant positive relationship between the internal perspective and efficient service delivery 
Table 7. Summary of the finding

\begin{tabular}{cccc}
\hline Hypotheses & Tools of Analysis & Models & Result \\
\hline $\begin{array}{c}\text { There is no relationship between financial perspective } \\
\left(X_{1}\right) \text { and agency productivity }\left(Y_{1}\right)\end{array}$ & Correlation & $X_{1} \leftrightarrow Y_{1}$ & $\begin{array}{c}p<0.05 ; \\
H_{1} \text { rejected. } \\
\text { Development and learning perspective }\left(X_{2}\right) \text { does not } \\
\text { affect agency productivity }\left(Y_{1}\right)\end{array}$ \\
$\begin{array}{c}\text { There is no significant relationship between customers' } \\
\text { perspective }\left(X_{3}\right) \text { and profitability }\left(Y_{2}\right) .\end{array}$ & Regression & $Y_{1}=a+b X_{2}$ & $\begin{array}{r}p<05 ; \\
H_{2} \text { rejected. } \\
p<0.05 ;\end{array}$ \\
$\begin{array}{c}\text { Internal perspective }\left(X_{4}\right) \text { and efficient service delivery } \\
\left(Y_{3}\right) \text { does not have any correlation }\end{array}$ & Correlation & $X_{3} \leftrightarrow Y_{2}$ & $\begin{array}{r}H_{3} \text { rejected. } \\
p<0.05 ; \\
H_{4} \text { rejected. }\end{array}$ \\
\hline
\end{tabular}

\subsection{DISCUSSION OF THE FINDINGS}

The study investigated improving public revenue agency and performance measurement using a balanced scorecard (BSC). Kasasbeh (2018) indicated that Balanced Scorecard plays a dual role as a measurement system and administrative system that links objectives, metrics, target levels and provide feedback for integral processes. The findings revealed that $65 \%$ variation in revenue agency performance can be attributed to the effectiveness and efficiency of their balanced scorecard components. This outcome is in line with the findings of Madsen (2013) who interviewed 39 managers of Scandinavian organizations and adopted the BSC, and found that; BSC improve processes related to performance measurement, budgeting, and strategy, organizational politics, and changes, broader cultural and social trends and finally it increased focus on being 'balanced' and take into account more than just financial performance measures. Furthermore, Koufteros, Verghese, \& Lucianetti, (2014) established that performance measure facilitates in employees' competence building which in turn enables improved performance.

Quesado et al (2018) documented that BSC allows organizations to build a high-performance culture, to the extent that it promotes the alignment of key indicators to the strategic objectives of the company in every organizational level. The primary purpose of the BSC is to help implement a strategy, Kaplan, and Norton $(1996,2001)$. First hypothesis outcome revealed that there is a relationship between the financial perspective and agency productivity. This aligned with research outcome on level of efficiency and effectiveness of operational cost conducted by (Wu, Lin and Chang, 2011; Suhendi, 2012; Christina and Sudana, 2013; Nur, 2013; Rumintjap, 2013; Angriani, 2014; Antariksa et al., 2014; Quezada et al., 2014; Sudaryo, 2015). In 2006, the state government passed a law to make LIRs financial autonomous and maximize to the betterment of the state significantly.

Secondly, it was discovered that development and learning perspective does affect agency productivity positively. On a percentage basis, $84.6 \%$ of the variance recorded in productivity is accounted for by development and learning perspective. This equally collaborated with research on learning and growth perspective on staff capability (Wu et al., 2011; Fooladvand et al., 2015) improvement of manpower quality (Wu et al., 2011; Suhendi, 2012), employees' education level (Hermawan, 2008), work experience (Hermawan, 2008), number of education and training (Suhendi, 2012; Christina and Sudana, 2013; Nur, 2013; Rumintjap, 2013; Angriani, 2014), with more adequate staff capability, improvement on manpower quality, training and development productivity level turned out to be remarkable.

Thirdly, there is a significant relationship between customers' perspective and profitability. This collaborated empirical findings on improving service quality (Wu et al., 2011; Nur, 2013; Quezada et al., 2014; Fooladvand et al., 2015), value of customer satisfaction (Hermawan, 2008; Sukesti, 2010; Tohidi et al., 2010; Wu et al., 2011; Aljardali et al., 2012; Effendi, 2012; Suhendi, 2012; Atafar et al., 2013; Rumintjap, 2013; Santhi et al., 2013; Angriani, 2014; Antariksa et al., 2014; Quezada et al., 2014; Fooladvand et al., 2015; Sudaryo, 2015) consistent with customer expectation (Atafar et al., 2013) and timely delivery (Fooladvand et al., 2015). Highly motivated employee enhanced performance which leads to organization success and productivity (Ratia \& Tuzlukaya, 2019). It implies that an organization that modifies its services to suit customers would experience a steady increase in patronage of services and the agency profitability will continue to grow.

Finally, an internal perspective and efficient service delivery correlate. This is line with research conducted on utilization of new technology (Suhendi, 2012; Aljardali et al., 2012), the capability of information system (Wu et al., 2011; Suhendi, 2012; Angriani, 2014; Fooladvand et al., 2015). The findings of the study subscribe to the fact that overall performance over the years improved significantly with a premeditated course of BSC integration into LIRS. 


\section{CONCLUSIONS}

Revenue is equivalent to the human blood in governance, it's not only important but imperative for general societal good. Financial performance occupies a significant place in the agency operation. However, other factors of a balanced scorecard, interrelated indicator and can promote positivity in strategic goals, boost learning productivity and efficiency in service delivery should always be re-examined to meet citizen's satisfaction leading to the economic efficiency of the enterprise. More so, they need to ensure process, procedure and pressured are mounted on an employee to be more productive, organized and citizens to file a tax return as at when due would bring better development in all ramifications. Based on the above, it is recommended that the agency, LIRS, should adopt more feedback mechanism from citizens and staff for a better strategy which serves as a manifestation of its progression, output of the mechanism will be important to encourage this process of better agency role. The implication of this feedback on service delivery should be identified and reported to all key stakeholders. Each local government areas and local council development areas in Lagos state that constitutes the State has certain peculiarities. The State government should find a way to harmonize and harness their needs to avoid a reduction in revenue generation over issues of nonperformance that may be associated with such division. Furthermore, it is important to recognize how to capture the informal sector towards improving agency revenue drive.

The state government should strengthen tax audit to discover organizations and individuals that ceased to file returns annually and companies that declare distrustful profits. Also, Balanced Score Card (BSC) reports should be made accessible to stakeholders in Lagos state and developing economies, in general, to be able to monitor progress in the areas of tax management and administration.

There is a need for government policies to be more citizen-friendly to aid the growth of businesses in the state and also boost the revenue drive in Nigeria and other developing economies. Also, more should be done in terms of the provision of infrastructural facilities, which can also assist in increasing revenue generation in developing economies. Also, other loopholes through which tax are being evaded can be blocked by embarking on more modern sophisticated technology with an appropriate database of all companies since Lagos is the economic capital of Nigeria. Finally, machinery should be put in place to monitor the impact of the implementation of strategic initiatives on the achievement of the BSC objectives to help the public agencies and organizations to better understand the performance drivers which can lead to more effective and efficient use of limited resources in developing economies.

\section{REFERENCES}

Abata M.A (2014). The Impact of tax revenue on the Nigeria economy (A Case Study of FBIR). Journal of Policy and Development Studies 9. (1) 109-121

Abuhashesh M., Al-Dmour R., \& Masa'deh R. (2019). Factors that affect employees' job satisfaction and performance to increase customers' satisfaction. Journal of Human Resources Management Research Article ID 354277.DOI: $10.5171 / 2019.354277$

Aguolu,O. (2004) Taxation and tax management in Nigeria, 3rd Edition, Enugu; Meridan Associates

Aidemark, L. (2001). The meaning of balanced scorecards in the health care organization. Financial Accountability and Management, 17(1), 23-40. doi:10.1111/1468-0408.00119

Amaratunga, D., Baldry, D., Sarshar, M., \& Newton, R. (2002). Quantitative and qualitative research in the built environment: Application of "mixed" research approach. Work Study, 51(1), 17-31. doi:10.1108/00438020210415488

Argentero, P., Bruni, A., Fiabane, E. M., \& Setti, I. (2012). Organizational change and work stress among mental health care staff. Methods, models, simulations and approaches: Towards a general theory of change, 661-671. doi:10.1142/9789814383332_0047

Armstrong, M. and Baron, A. (1998). Performance management handbook, IPM, London.

Asaolu, T.O., Dopemu, S.O. and Monday, J.U. (2015). Impact of tax reforms on revenue generation in Lagos State: A time series analysis. Research Journal of Finance and Accounting, 6, 85-96.

Asiaei, K., \& Jusoh, R. (2014). Determinants of Performance Measurement Practices: Toward a contingency framework. International Journal of Management Excellence, 2(3), 257. doi:10.17722/ijme. v2i3.104

Atkinson, A.A. and McCrindell J.Q. (1997). Strategic performance measurement in government, CMA Magazine, April, pp. 20-23.

Baird, K. (2017). The effectiveness of strategic performance measurement systems, International Journal of Productivity \& Performance Management, 66(1), 3-21.

Behn, R. D. (2003). Why Measure Performance? Different purposes require different measures. Public Administration Review, 63(5), 586-606. doi:10.1111/1540-6210.00322 
Bilkhu-Thompson, M.K. (2003). "A Process Evaluation of a Health Care Balanced Scorecard," Journal of Health Care Finance, 30(2), 37-64.

Biswanath C.,(2007). Is it meaningful to measure performance in public sector? Vidyanagar University Journal of Commerce, 12, $37-38$.

Blessing S., Endurance, O. S., \& Stephanie G. (2017). The appraisal of taxation as a source of revenue to Lagos state board of internal revenue (Case of Lagos State, Nigeria). Research Journal of Finance and Accounting, 8(23).

Bloch, C., \& Bugge, M. M. (2013). Public sector innovation-from theory to measurement. Structural Change and Economic Dynamics, 27, 133-145. doi: 10.1016/j.strueco.2013.06.008

Bourne, M., Mills, J., Wilcox, M., Neely, A., \& Platts, K. (2000). Designing, implementing and updating performance measurement systems. International Journal of Operations \& Production Management, $20(7), 754-771$. Doi:10.1108/01443570010330739

Bowling, A. (1997). Health outcome measures in primary and out-patient care. Quality and Safety in Health Care, 6(2), 115116. doi:10.1136/qshc.6.2.115-b

Breuer, E., De Silva, M., \& Lund, C. (2018). Theory of change for complex mental health interventions: 10 lessons from the programme for improving mental healthcare. Global Mental Health, 5. doi:10.1017/gmh.2018.13

Byrnes, J., \& Dollery, B. (2002). Local government failure in Australia? An empirical analysis of New South Wales. Australian Journal of Public Administration, 61(3), 54-64. doi:10.1111/1467-8500.00284

Carlos, W. E., Kaplan, R., Lowndes, D. H., \& Norton, D. P. (1992). Microwave absorption in YBCO/PrBCO Superlattices. MRS Proceedings, 275. doi:10.1557/proc-275-79

Carter, N. (1991). Learning to Measure Performance: The use of indicators in organizations. Public Administration, 69(1), 85-101. doi:10.1111/j.1467-9299.1991.tb00783.x

Carton, R.B., Hofer C.W., Measuring organizational performance. Unpublished, Edward Elgar, Northampton, MA, USA, 2006. doi: $10.4337 / 9781847202840$

Center for ToC (2013). TOC Origins. Retrieved July 2, 2018, from http://www.theoryofchange.org/what-is-theory-ofchange/toc-background/toc-origins/

Chai, K., Ding, Y., \& Xing, Y. (2009). Quality and customer satisfaction spillovers in the mobile phone industry. Service Science, 1(2), 93-106. doi:10.1287/serv.1.2.93

Chan, Y.-C.L. and Ho, S.J.K. (2000). Performance measurement and the use of balanced scorecard in Canadian hospitals. Advances in Management Accounting. 19, 145-69.

Chang, L., Lin, S. W. and Northcott, D. N. (2002). The NHS performance assessment framework, a balanced scorecard approach. Journal of Management in Medicine, 16, 5; 345-358.

Chiang, Han-yi (2006). The Study of Performance Evaluation in Liner Shipping Industry by Linking.

Chow, C. W., Ganulin, D., Haddad, K., \& Williamson, J. (1998). The Balanced Scorecard: A potent tool for energizing and focusing healthcare organization management. Journal of Healthcare Management, 43(3), $263-280$. doi:10.1097/00115514-199805000-00010

Christopher Pollitt and Geert Bouckaert (2011) Public management reform: A comparative analysis - new public management, governance, and the neo-Weberian state. International Review of Administrative Sciences, 78(1), 180182. doi: $10.1177 / 0020852312437323$

Clark, H., \& Anderson, A.A. (2004). Theories of Change and Logic Models: Telling them apart. Retrieved July 9,2018 fromhttps://www.theoryofchange.org/wpcontent/uploads/toco_library/pdf/TOCs_and_Logic_Models_forAEA.pdf

Colquitt, Le Pine, and Wesson. (2011). Organizational Behavior: Improving performance and commitment in the work place. New York: McGraw-Hill Companies. Inc

Cucuruzan, R. E., Gheorghiu, R., Turlea, G., \& Andrei, S. (2010). Knowledge-Based Entrepreneurship in Romania. SSRN Electronic Journal. doi:10.2139/ssrn.1670144

Dennis A., \& Emmanuel O. (2014). The impact of taxation on revenue generation in Nigeria: A study of federal capital territory and selected states. International Journal of Public Administration and Management Research (IJPAMR), 2(2).

Dinçer, H., Yüksel, S., Korsakienè, R., Raišienè, A. G., \& Bilan, Y. (2019). IT2 Hybrid Decision-Making Approach to Performance Measurement of Internationalized Firms in the Baltic States. Sustainability, 11(1), 296. doi:10.3390/su11010296

Dixon, J., Kouzmin, A., \& Korac-Kakabadse, N. (1998). Managerialism - something old, something borrowed, little new. International Journal of Public Sector Management, 11(2/3), 164-187. doi:10.1108/09513559810216483

Edis, M. (1995). Performance Management and Appraisal in Health Services. London: Kogan Page.

Egbunike, F. C., Emudainohwo, O. B., \& Gunardi, A. (2018). Tax revenue and economic growth: A study of Nigeria and Ghana. Signifikan: Jurnal IImu Ekonomi, 7(2), 213-220. doi:10.15408/sjie.v7i2.7341

Elefalk, K.,( 2001)"The Balanced Scorecard of the Swedish Police Service: 7000 officers in total quality management project", Total Quality Management, 12(7/8), pp. 958-966,. 
Etim, R. S. \& Agara, I. G. (2011). The Balanced Scorecard: The new performance management paradigm for Nigerian firms. International Journal of Economic Development Research and Investment. 2(3), 64-73.

Fisher N. I., (2019) A comprehensive approach to problems of performance measurement. J. R. Statist. Soc. A (2019) 182, Part 3, pp. 1-36

Fletcher, H. D. and Smith, D. B. (2004) Managing for value: Developing a performance measurement system integrating economic value added and the balanced scorecard in strategic planning. Journal of Business Strategies, 24 (1), 1-18.

Gabor, G. (2001). Kaplan, R. S./Norton, D. P., The strategy-focused organization. Schmalenbach Business Review, 53(3), 240-241. doi:10.1007/bf03396637

Gibson, J. L, Ivancevich, J. M., Donnelly, J. H., \& Konopaske, R. (2012). Organizations: Behaviour, structure, processes (14th ed.). New York, NY: McGraw-Hill Irwin

Gould, A. M., Bourk, M. J. \&Joullié, J. E. (2017). From The Industrial Revolution to Trump: Six periods of changing perceptions of American business managers. Journal of Management History, 23(4),471-488

Greiling, D. (2005). Performance measurement in the public sector: the German experience. International Journal of Productivity and Performance Management, 54(7), 551-567. doi:10.1108/17410400510622223

Guimaraes, T., \& Armstrong, C. (1998). Empirically testing the impact of change management effectiveness on company performance. European Journal of Innovation Management, 1(2), 74-84. doi:10.1108/14601069810217257

Hamri., Asmawi M., \& Rasyid U.(2019). The effect of responsibility and leadership on job performance of high school at North Jakarta. International journal of Scientific Research and Management(IJSRM) Vol. 7. ISSN 2321-3418

Hassan S. S., (2018) Performance measurement: How far it has traveled and where is it headed. International Journal of Economics, Commerce and Management United Kingdom. Vol. VI, Issue 4, April 2018 ISSN 23480386

Ho, S. J. K. and Chan, Y. L. (2002). Performance measurement and implementation of balanced scorecards in municipal governments. The Journal of Government Financial Management, 51, (4) 8-19.

Ho, S. J. K. and Kidwell, L. A. (2000). A survey of management techniques implemented by municipal administrators. The Government Accountant Journal, 49,1; 46-52.

Hoque, Z. (2005), "Securing institutional legitimacy or organizational effectiveness? A Case examining the impact of public sector reform initiatives in an Australian Local Authority", International Journal of Public Sector Management, 18 (3), 367-382.

Hoque, Z., \& James, W. (2000). Linking balanced scorecard measures to size and market factors: Impact on organizational performance. Journal of Management Accounting Research, 12(1), 1-17. doi:10.2308/jmar.2000.12.1.1

Hoque, Z., Mia, L., \& Alam, M. (2001). Market competition, computer-aided manufacturing and use of multiple performance measures: An empirical study. The British Accounting Review, 33(1), 23-45. doi:10.1006/bare.2000.0149

Hristov I., Chirico A., \& Appolloni.A (2019). Sustainability Value Creation, Survival, and Growth of the Company: A critical perspective in the sustainability balanced scorecard (SBSC). Journal of Sustainability 2019, 11, 2119.

Ibrahim, M., \& Murtala, S. (2015). The relevance of balanced scorecard as a technique for assessing performance in the Nigerian banking industry. European Journal of Business, Economics and Accountancy 3(4), 71-80.

Irma P., (2018) Theory of Change for Development: Understanding, Usage, and Influence Division of Risk Management and Societal Safety, Faculty of Engineering, Lund University, Lund

Isaac Mwita, J. (2000). Performance management model. International Journal of Public Sector Management, 13(1), 1937. doi:10.1108/09513550010334461

Isoraite M. (2008). The Balanced Scorecard Method: From theory to practice. Intellectual Economics 2008, 1(3), 18-28

Išoraitè M. (2008). The Balanced Scorecard Method: From theory to practice. Intellectual Economics, 1(13), 18-28. Retrieved from https://images.template.net/wp-content/uploads/2016/07/01132855/Process-PerformanceSample.pdf

Jääskeläinen, A., \& Lönnqvist, A. (2011). Public service productivity: How to capture outputs? International Journal of Public Sector Management, 24(4), 289-302. doi:10.1108/09513551111133461

Kaplan, R. S. and D. P. Norton (1992). The Balanced Scorecard - Measures that drive performance. Harvard

Kaplan, R. S. (2001). Strategic Performance Measurement and management in nonprofit organizations. Nonprofit Management and Leadership, 11(3), 353-370. doi:10.1002/nml.11308

Kaplan, R. S., \& Norton, D. P. (1996). Strategic learning \& the balanced scorecard. Strategy \& Leadership, 24(5), 18-24. doi:10.1108/eb054566

Kaplan, R. S., \& Norton, D. P. (1998). Putting the balanced scorecard to work. The Economic Impact of Knowledge, 315324. doi:10.1016/b978-0-7506-7009-8.50023-9

Kaplan, R. S., \& Norton, D. P. (2001). Transforming the balanced scorecard from performance measurement to strategic management: Part II. Accounting Horizons, 15(2), 147-160. doi:10.2308/acch.2001.15.2.147

Karimi \& Muiruri, Z. (2015). The influence of the balanced score card on performance of public sector organizations in Kenya. Science Journal of Business and Management, 3(5), 150. doi: 10.11648/j.sjbm.20150305.13 
Kasasbeh, I. (2018). Problems of management accounting implementation. The case of balanced scorecard implementation within Jordanian commercial banks, International Journal of Academic Research in Accounting, Finance and Management Sciences $8 \quad$ (2): $200-207$. http://dx.doi.org/10.6007/IJARAFMS/v8-i2/4271.

Kelly, J. M., \& Swindell, D. (2002). A multiple-indicator approach to municipal service evaluation: correlating performance measurement and citizen satisfaction across jurisdictions. Public Administration Review, 62(5), 610-621. doi:10.1111/1540-6210.00241

Kloot, L., \& Martin, J. (2000). Strategic performance management: A balanced approach to performance management issues in local government. Management Accounting Research, 11(2), 231-251. doi:10.1006/mare.2000.0130

Koufteros, X., Verghese, A. \& Lucianetti, L. (2014). The effect of performance measurement systems on firm performance: A cross-sectional and a longitudinal study. Journal of Operations Management, 32(6), 313-336.

Laking, R. (2005). Agencies: Their benefits and risks. OECD Journal on Budgeting, 4(4), 7-25. doi:10.1787/budget-v4art19-en

Lewis, J. (2015). The politics and consequences of performance measurement. Policy and Society, 34(1), 1-12. doi:10.1016/j.polsoc.2015.03.001

Lilian Chan, Y. (2004). Performance measurement and adoption of balanced scorecards. International Journal of Public Sector Management, 17(3), 204-221. doi:10.1108/09513550410530144

Madsen, D. (2013). The Adoption of the Balanced Scorecard in Scandinavia: A qualitative exploration of motives and rationales. European Journal of Business Research, 13(2), 99-109. doi:10.18374/ejbr-13-2.12

Madsen, D. (2015). The balanced scorecard in the context of SMEs: A literature review. Review of Business Research, 15(3), 75-86. doi:10.18374/rbr-15-3.8

Micheli, P., \& Mura, M. (2017). Executing strategy through comprehensive performance measurement systems. International Journal of Operations \& Production Management, 37(4), 423-443. doi:10.1108/ijopm-08-2015-0472

Modell, S. (2004). Performance measurement myths in the public sector: A research note. Financial Accountability and Management, 20(1), 39-55. doi:10.1111/j.1468-0408.2004. 00185.x

Moon, P., \& Fitzgerald, L. (1996). Delivering the goods at TNT: The role of the performance measurement system. Management Accounting Research, 7(4), 431-457. doi:10.1006/mare.1996.0024

Mooraj, S., Oyon, D., \& Hostettler, D. (1999). The Balanced scorecard: A necessary good or an unnecessary evil? European Management Journal, 17(5), 481-491. doi:10.1016/s0263-2373(99)00034-1

Mulgan, G. and Albury, D., (2003). Innovation in the public sector. Strategy Unit, Cabinet Office, UK. National Audit Office, 2006, Achieving innovation in central government organisations: detailed research findings.

Niven, Paul R. (2003). Balanced scorecard, step-by-step for government and nonprofit agencies. London: John Wiley Sons Inc.

OECD (2002), Distributed public governance: Agencies, authorities and other government bodies, OECD, Paris.

Olve, N., Roy, J., and Wetter, M., (1999). Performance drivers: A practical guide to using the balanced scorecard. London, John Wiley \& Sons

Otley, D.(1999). Performance management: A framework for management control systems research. Management Accounting Research, 10(4), 363-382. doi:10.1006/mare.1999.0115

Protti, D. (2002). A proposal to use a balanced scorecard to evaluate Information for health: An information strategy for the modern NHS (1998-2005). Computers in Biology and Medicine, 32(3), 221-236. doi:10.1016/s0010-4825(02)00017-3

Quesado, P. R., Guzmán, B. A., \& Rodrigues, L. L. (2013). Balanced scorecard adoption in Portuguese organizations: Contingent and institutional variables. Intangible Capital, 9(2). doi:10.3926/ic.451

Quesado, P., Aibar Guzmán, B., \& Lima Rodrigues, L. (2018). Advantages and contributions in the balanced scorecard implementation. Intangible Capital, 14(1), 186. doi:10.3926/ic.1110

Quinlivan, D. (2000). Rescaling the balanced scorecard for local government. Australian Journal of Public Administration, 59,$4 ; 36-41$.

Radin, B. (2006). Challenging the performance movement: accountability, complexity and democratic values. Washington, D.C.: Georgetown University Press

Ratia L. R., \& Tuzlukaya S. E., (2019). The relationship of the dimensions of job satisfaction to job performance: A case study of a multinational company in Lesotho. Journal of Research in Emerging Markets, 1(3), 8-19. https://doi.org/10.30585/jrems.v1i3.356

Retolaza, I. (2011). Theory of Change: A thinking and action approach to navigate in the complexity of social change processes. Hivos/UNDP/Democratic Dialogue.

Ruzita, J., Azhar, R., \& Abu Hasan, H. (2012). Performance measurement practices of public sectors in Malaysia. Journal of Global Strategic Management, 1(6), 42-42. doi:10.20460/jgsm.2012615785

Sanchez, R., \& Toharia, L. (2000). Temporary Workers and Productivity: The case of Spain. Applied Economics

Scheibeler, A. A. (2001). Balanced Scorecards. Balanced Scorecard für KMU, 1-21. doi:10.1007/978-3-642-97757-2_1 
Schick, A. (2001). "Getting Performance Measures to Measure Up." Chapter 3 in Quicker, Better, Cheaper: Managing performance in American government, Dall W. Forsythe, Editor (Albany, NY: The Rockefeller Institute Press): 39-60.

Schmenner, R. W., \& Vollmann, T. E. (1994). Performance Measures: Gaps, false alarms, and the "Usual Suspects". International Journal of Operations \& Production Management, 14(12), 58-69. doi:10.1108/01443579410072391

Schmitz Jr., J. (2005). What Determines Productivity? Lessons from the dramatic recovery of the U.S. and Canadian iron ore industries following their early 1980s crisis. Journal of Political Economy, 113(3), 582-625. doi:10.1086/429279

Schneider, I. (1995). Osborne, D. and Gaebler, T. 1992. Reinventing Government. New York, NY. Journal of Leisure Research, 27(3), 302-304. doi:10.1080/00222216.1995.11949751

Shapiro, I. (2006). Extending the Framework of Inquiry: Theories of change in conflict interventions. Berghof Handbook, (5).

Soderberg, M., Kalagnanam, S., Sheehan, N. T., \& Vaidyanathan, G. (2011). When is a balanced scorecard a balanced scorecard? International Journal of Productivity and Performance Management, 60(7), 688-708. doi:10.1108/17410401111167780

Sonson S., Kulatunga U., \& Pathirage C. (2017). Performance measurement and management in construction: A Conceptual Framework. University of Salford, Salford, UK.

Stein, D., Valters, C. (2012). Understanding Theory of Change in International Development. The Asia Foundation.

Stewart, A. C., and J. Carpenter, H., (2001). The Balanced scorecard: Beyond reports and rankings. Planning for higher education 29 (2): 37-42.

Su, S., \& Baird, K. (2017). The association between performance appraisal systems, work-related attitudes and academic performance. Financial Accountability \& Management, 33(4), 356-372. doi:10.1111/faam.12128

Talbot, R. C., Leuven, K. U., \& Caulfield J. (2000). The idea of agency researching the agencification of the (public service) world. Paper for the American Political Studies Association Conference, Washington DC, August 2000.

Taplin, Dana, Heléne Clark, Eoin Collins and David L. Colby (2013). Theory of Change Technical Papers: A Series of Papers to support Development of Theories of change Based on Practice in the Field. ActKnowledge: New York.

Trudel, J. (1997). The Balanced Scorecard: Translating strategy into action by Robert S. Kaplin and David P. Norton. Boston, MA: Harvard Business School Press, 1996. $322+$ xi pages. \$dollar;29.95. Journal of Product Innovation Management, 14(3), 235-237. doi:10.1016/s0737-6782(97)89410-6

Van de Walle, S., \& Bouckaert, G. (2007). Perceptions of Productivity and Performance in Europe and The United States. International Journal of Public Administration, 30(11), 1123-1140. doi:10.1080/01900690701225309

Van Oosteroom, R. (2002). Distributed Public Governance: Agencies, authorities and other autonomous bodies in the Netherlands. OECD Journal on Budgeting, 2(1), 103-120. doi:10.1787/budget-v2-art5-en

Vogel, I. (2012). Review of the use of "Theory of Change" in international development. DFID,

Weiss, C. (1995). Nothing as Practical as Good Theory: Exploring Theory-Based Evaluation for Comprehensive Community Initiatives for Children and Families

Weiss, J. A., Osborne, D., Gaebler, T., \& Review, N. P. (1995). Reinventing Government: How the entrepreneurial spirit is transforming the public sector. The Academy of Management Review, 20(1), 229. doi:10.2307/258896.

Wilson, C., Hagarty, D., Gauthier, J.,( 2003) Research using the balanced scorecard in the public sector. Journal of Corporate Real Estate, 6(1), 53-63,.

Yadav, N., \& Sagar, M. (2013). Performance measurement and management frameworks: Research trends of the last two decades. Business Process Management Journal, 19(6), 947-971. 